\title{
Six New Records of Predaceous Mites Associated with some Trees from Riyadh, Saudi Arabia
}

Fahad J. Al-Atawi

Dept. of Plant Protection. College of Food and Agriculture Sciences, King Saud Univ., P.O. Box 2460, Riyadh 11451, Kingdom of Saudi Arabia, E-mail: falatawi@ksu.edu.sa

\begin{abstract}
Ten predaceous mite species, belonging to eight families (Ascidae, Bdellidae, Caligonellidae, Camerobiidae, Cheyletidae, Cunaxidae, Phytoseiidae and Stigmaeidae), were collected from fruit and timber trees in Riyadh, Saudi Arabia. Out of these ten species, six (Arctoseius cetratus (Sellnick), Decaphyllobius gersoni Bolland, Molothrognathus sp., Neoseiulus barkeri Hughes, Neoseiulus mumae(Shehata \& Zaher), and Scutascirus tactus Chaudhari) are fristly rcorded in Saudi Arabia. In addition, Agistemus vulgaris Soliman \& Gomaa, Euseius scutalis (Athias- Henriot), and Spinibdella bifurcata Atyeo are reported for the first time on fruit trees in Saudi Arabia, while Hemicheyletia bakeri (Ehara) was previously recorded on pin timber trees. Some of these predaceous mites, recorded in this study, can be used as biological agents against phytophagous mites in Saudi Arabia.
\end{abstract}

Key Words: Phytoseiidae, Predaceous mites, Fruit Crops, Saudi Arabia.

\section{INTRODUCTION}

The predaceous mites play an important role in suppressing other mite pests in different habitats attacking different plant hosts (Amitai, 1992). Different mite families including potentially important predaceous species are found throughout the world on plants and soils. Members of phytoseiid and stigmaeid mites are very essential biological control agents for mite pests, e.g. tetranychids, tenuipalpids and eriophyids (Helle \& Sabelis, 1985; Santos \& Laing 1985; Villanueva \& Harmsen, 1998 and Kheradmand et al., 2007).

Mite fauna of Saudi Arabia (SA) has received a very little consideration and the groundwork for essential taxonomic, biological, and ecological studies of agricultural mites is extremely rare (AlAtawi \& Halawa, 2011 and Al-Shammery, 2009). Consequently, predatory mites have been poorly studied in SA resulting in insufficient information about the biology and ecology of these beneficial mites. Such information is highly required for successful integrated pest management (IPM), biological control, and organic farming programs.

However, out of 88 predatory mite species, belonging to 59 genera and 25 families, reported on diflerent plants and soil in SA, only 25 species were recorded on fruit trees ( Al-Youssif, \& Soliman, 1979: Soliman \& Al-Yousif, 1979: Hammad et al., 1981: Dabbour \& Abdel-Aziz, 1982; Al-Khalifa \& Bayoumi, 1983; Bayoumi \& Al-Khalifa. 1983; Rostom, 1993: Al-Ahmed, 2000: Al-Rehiayani \& Fouly, 2005 \& 2006: Al-Shammery, 2009. Fouly \& Al-Rehiayani, 2011 and Al-Atawi, 2011). This study aimed to investigate predatory mites associated with some fruit and timber trees in Riyadh, Saudi Arabia.

\section{MATERIALS AND METHODS}

A survey of mite collection from fruit and timber trees was conducted in five localities surrounding Riyadh city (Al-Deraiya, Al-Ammaria, Al-Hayer, Al-Oiayna and Al-Waseel). The fruit trees included vine (Vitis vinifera), citrus (Citrus spp.), apple (Malus domestic) and date palm (Phoenix dactylifera). Only one species of timber trees was surveyed (Tamarix aphylla). During the time of mite collection, tumors were observed on bark of Tamarix aphylla. At each locality, sampling process was carried out irregularly from October, 2008 to December, 2010. Samples included plant foliages and surface soil surrounding the trees.

Mites were collected from leaves and soil samples by using a fine hair brush for identification based on Krantz (1978), Atyeo (1960), Evans (1963), Smiley (1992), and Zhi-Qiang Zhang (2003). All specimens are deposited in the King Saud University Museum of Arthropod (KSMA), College of Food and Agriculture Sciences, King Saud University.

\section{RESULTS AND DISCUSSION}

\section{1- Mesostigmata:}

Family Ascidae Voigots and Oudemans Arctoseius cetratus (Sellnick)

Material cxamined: Al-Ammaria. XI. III. 2009. 1 in citrus groove soil (Citrus spp.).

Family Phytoseiidae Berlese Neoseiulus barkeri Hughes

Material examined: Al-Hayer. XXIII. IV.2009. 2 on leaves of apple (Malus domestica).

Neoseiulus mumae (Shehata and Zaher. 1969) (= Amblyseins mumue Shehata and Zaher, 1969)

Material examined: Al-Oiayna. 15.V. 2009. 
2 in citrus groove soil (Citrus spp.).

Euseius scutalis (Athias- Henriot).

Material examined: Al-Hayer, 22. X. 2009. 1 i $\hat{\delta}$ on leaves of grape vine (Vitis vinifera).

\section{2- Prostigmata:}

Family Bdellidae Duges

Spinibdella bifurcata Atyeo

Material examined: Al-Deraiya, VII. VI. 2009.

$1 \%$ on fronds of date palm (Phoenix dactilyfera).

Family Caligonellidae Grandjean Molothrognathus sp.

Material examined: Al-Wassel, XXV. XII.2010, 9 on Tamarix aphylla leaves (Tamaricaceae)

Family Camerobiidae Southcott

Decaphyllobius gersoni Bolland

Material examined: Al-Wassel, XXV. XII.2010,

8 ㅇ 2 on Tamarix aphylla leaves (Tamaricaceae)

Family Cheyletidae Leach

Hemicheyletia bakeri (Ehara)

Material examined: Al-Wassel, XXV. XII.2010, 3 q in Tamarix aphylla (Tamaricaceae)

Family: Cunaxidae Thor

Scutascirus tactus Chaudhari

Material examined: Al-Hayer, XVIII. III. 2009, $1 \%$ in citrus groove soil (Citrus spp.).

Family: Stigmaeidae Oudemans

Agistemus vulgaris Soliman and Gomaa

Material examined: Al-Hayer, XVIII . XII. 2008, 19,1 on leaves of grape vine (Vitis vinifera).

Ten mesostigmatid and prostigmatid predatory mite species belonging to ten genera and eight families (Ascidae, Bdellidae Caligonellidae, Camerobiidae, Cheyletidae, Cunaxidae, Phytoseiidae, and Stigmaeidae) were collected from five species of trees covering five different localities (Al-Deraiya, Al-Ammaria, Al-Hayer, Al-Oiayna, Al-Waseel) in Riyadh. Seven species were recorded on four fruit trees (Citrus spp., Malus domestica, Phoenix dactilyfera, Vitis vinifera), while the other three mite species were found on (Tamarix aphylla).

Six mite species, namely $A$. cetratus, $D$. gersoni, Molothrognathus sp., $N$. mumae, $N$. barkeri, and $S$. tactus are recorded for the first time in SA, whereas A. vulgaris, E scutalis, and S. bifurcata Atyeo are noted for the first time on fruit trees in Saudi Arabia. The last three species were previously recorded on different plants other than fruit trees (Lettuce sativa, Solanum melongena, and Pinus spp.) (Al- Atawi, 2011, Al-Shammery, 2009, Al-Khalifa and Bayoumi, 1983), respectively. Hemicheyletia bakeri (Ehara) was earlierly recorded on pin timber trees (Pinus spp.) (Al-Youssif and Soliman, 1979).

Among mesostigmated species recorded in this study, the two phytoseiid mites, $N$. barkeri and $E$. scutalis play important role in biological control and pest management programs (Mcmurtry, 1997). The applications of $E$. scutalis and $N$. barkeri against greenhouse whiteflies (Bemisia tabaci Gannadius) and phytophagous mite (Polyphagotarsonemus latus (Banks)) were proposed by Nomikou et al., 2002 and Urigerson \& Phyllis, 2007 respectively. However. $N$. mumae has not been used yet as a biological control agent in pest management programs. This species was only recorded in Egypt and attacks T. urticae and scale insects (Shehata and Zaher, 1969).

None of prostigmated species recorded in this study has been previously applied in biological control and pest management programs. Yet, the genus Agistemus Summers is one of the most important spider mites predators (Santos and Laing 1985; Kheradmand et al., 2007). Agistemus vulgaris was originally described in Egypt and preys on phytophagous mites (Zaher, et al., 1986). This mite is well distributed in different areas in Riyadh (Al-atawi, 2011).

In Saudi Arabia, among these four mite species previously recorded (A. vulgaris, E. scutalis, $S$. bifurcata, and $H$. bakeri) and reported in this study, only $E$. scutalis was evaluated as a biological control agent against three phytophagous tetranychid (T. urticae, Eutetranychus orientalis Klein, and Oligonychus afrasiaticus McGregor) under laboratory conditions (Al-Shammery, 2009). Therefore, further research should focus on these predatory mites as biocontrol agents. These results can be used to improve IPM programs by using the local natural enemies in controlling local or invasive pests in SA.

\section{ACHNOLEDGMENTS}

The author wishes to express his deep gratitude to the members of Acarology lab. at King Saud University for their help, support, and cooperation. Also, deep thanks are due to Dr. Abd El-Satar Metwally for his help in this work. This work is supported by King Saud University.

\section{REFERENCES}

Al-Ahmed, A. M. 2000. Population dynamics of arthropods associated with cow manure inside and outside pens in dairy farms in Alkharj region, Saudi Arabia. J. King Saud Univ., 12:21-30.

Al-Atawi, F. J. 2011. Phytophagous and predaceous mites associated with vegetable crops from Riyadh, Saudi Arabia. Saudi J. Biological Sciences (In press).

Al-Atawi, F. J. and Halawa, A. M. 2011. New records of Eriophyoid mites (Acari: Prostigmata: Eriophyoidea) from Saudi Arabia. Pakistan J. B. 
S., DOI: 10, 3923.

Al-Khalifa, M. S. and Bayoumi, B. M. 1983. Distribution of soil mites and collembolans under Pine trees in Riyadh region, Saudi Arabia. Acta Arachol., (1983), 32: 27-36.

Al-Rehiayani, S. A. and Fouly, A. H. 2005. Cosmolaelaps simplex (Berlese) a polyphagous predatory mite feeding on root-knot nematode Meloidogyne javanica and citrus nematode Tylenchulus semipenetrans. Pakistan Joumal of Biological Sciences 8 (1): 168-174.

Al-Rehiayani, S. A. and Fouly, A. H. 2006. Mycetoglyphus qassimi and Tyrophagous putresentiae, two acarid mites recovered from palm fields, feeding on root-not nematode Meloidogyne javanica in Al-Qassim area, Saudi Arabia. JKAU: Met., Env. \& Arid Land Agric. Sci., 17(2): 3-16.

Al-Shammery, K. A. 2009. Different biological aspects of the predaceous mite Euseius scutalis (Athias-Henriot) and the effects due to feeding on three tetranychid mites in Saudi Arabia. Asian J. Biol. Sci., 3:77-84.

Al-Youssif, M. S. and Soliman, Z. R. 1979. Cheyletid mites of Saudi Arabia with a key to species (Acari: Acariformes: Prostigmata). Bull. Soc. Ent. Egypte., 62: 213-218.

Amitai. S. 1992. New records of Phytoseiid mites (Acarina: Phytoseiidae) from Cyprus. Entomolgia Hellenica, 10: 19-20.

Atyeo, W. T. 1960. A revision of the mite family Bdellidae in North and central America (Acarina, Prostigmata). Science Bulletin. Kansas University.Vol.XL. No. 8.

Bayoumi, B. M. and Al-Khalifa, M. S. 1983. Soil mites and collembola from Al-Qasim Province, Saudi Arabia. Arab Gulf J. science. Res., 1(1) 179-186.

Dabbour, A. I. and Abdel-Aziz, M. I., Abdel-Aziz. 1982. Scientific note on Acarina in Saudi Arabia J. Coll. Agric. King Saud Univ., Vol. 4, 113-116.

Evans, G. O. 1963. Observation on the classification of the family Otopheidomenidae (Acari: Mesostigmata) with description of two new species. Ann. Mag. Nat. Hist., 5: 609.613.

Fouly, A. H. and Al-Rehiayani. S. M. 2011. Predaceous mites in Al-Qassim region. Saudi Arabia, with description of two new Laelapidae species (Acari: Gamasida: Laelapidae). Journal of Entomology, 8(2):139-151.

Hammad, S. M., Kadous, A.A and Ramadan. M. M. 1981. Insects and mitesa date palm in the Eastern Province of Saudi Arabia. Proc. Saudi Biol. Soc., 5. (Abha conf. 1981).

Helle, W., and Sabelis, M. W. 1985. Spider mites: their biology, natural enemies and control, vol.1B.Elsevier, Amsterdam.John, T. Fletcher and Richard, H. Gaze. 2008. Mushroom pest and disease control. Aademic press, an imprint of Elsevier, 187pp.

Kheradmand, K.; Kamali, K.; Fathipour, Y.; Goltpeh, E. M.; Uckermann, E. E. 2007. Thermal requirement for development of Sanacassania drodinovi (Acari: Acaridae) on Mashroom. J. Econ. Entomol., 100: 1098-1103.

Krantz, G. W. 1978. A manual of acarology. Second edition. Oregon State Univ. Stores, Inc. Corvallis., $509 \mathrm{pp}$.

McMurtry, J. A. 1997. Life-styles of phytoseiid mites and their roles in biological control. Annual Review of Entomology, 42: 291-321.

Nomikou, M.; Janssen A.; Schraag, R. and Sabelis, M. V. 2002. Phytoseiid predators suppress populations of Bemisia tabaci on cucumber plants with alternative food. Exp. Appl. Acarol., 27(1-2):57-68.

Rostom, Z. M. 1993. Survey of Granivorous and non-granivorous insects and mites of stores in Saudi Arabia. J. Stored Prod., Res., 29(1): 27-31.

Santos, N. A. and Laing, J. E. 1985. Stigmaeid predators in W. Hell And M. W. Sabelies (Editors), Spider mites, their biology, natural enemies and control, Vol. 1B Elsevier Scince Publ., Amestrdam, Netherlands, 197-203.

Shehata, K. K. and Zaher, M. A. 1969. Two new species in genus Amblyseius in URA (Acarina: Phytoseiidae). Acarologia 11:175-179.

Smiley R. L. 1992. The predatory mite family Cunaxidae of the world with new classfication. systematic entomology laboratory, Agricultural Resarch service, USDA, Beltsvile, Maryland 20705. USA. 131-134.

Soliman Z. R. and Al- Yousef, M. S. 1979. Prostigmatid mites of Saudi Arabia (Acariformes :Acariformes: Prostigmata)Bull. Zooi.Egypt,29: $82-86$.

Urigerson and Phyllis G. W. 2007. Review mites for the control of pests in protected cultivation. Pest Manag.Sci. 63:658-676.

Villanueva, R. T. and Harmsen, R. 1998. Studies on the role of the stigmaeid predatore Zetzetellia mali in the acarine system of Apple foliage. Proceeding of the entomological socity of Ontario, 129: 149-155.

Zaher, M. A. 1986. Predaceous \& non phytophagous mites in Egypt. Project No. EG-A RS- 30. Grant No. FG- EG-138.

Zhi-Qiang Zhang. 2003. Mites of greenhouses, School of life scienes. Fudan University, Shanghai, China $243 \mathrm{PP}$. 